\title{
Cure for Empire: The 'Conquer-Russia-Pill', Pharmaceutical Manufacturers, and the Making of Patriotic Japanese, 1904-45
}

\author{
HOI-EUN KIM* \\ Department of History, Texas A\&M University, College Station, TX 77843-4236, USA
}

\begin{abstract}
Seirogan, a popular anti-diarrhoeal pill, is arguably one of the most successful pharmaceutical products of modern Japan. What is less known is that the Japanese army initially developed Seirogan during the Russo-Japanese War as the 'Conquer-Russia-Pill', which was later marketed to the public by private manufacturers. Previous scholars have emphasised the top-down governmental method of mobilising private sectors to manipulate public opinion for the cause of external imperialist expansion and domestic stability during wartime Japan. But the matrix that the Conquer-Russia-Pill allows us to glimpse is an inverted power relation among the state, commercial sectors, and imperial citizens. While the Japanese government remained indifferent if not hostile to jingoistic pharmaceutical manufacturers who could easily disrupt international relations, pharmaceutical companies quickly recognised and exploited the opportunities that the Conquer-Russia-Pill and its symbolism provided under the banner of the empire. In turn, Japanese consumers reacted to commercial sermons carefully anchored in patriotic and militaristic discourses and images by opening their wallets. In other words, the popularity of the Conquer-Russia-Pill was a culmination of the convergence of a governmental initiative to enhance military capabilities, the commercial ingenuity of pharmaceutical manufacturers, and a consumer response to patriotic exhortations.
\end{abstract}

Keywords: Seirogan, Conquer-Russia-Pill, Japan, Imperialism, Russo-Japanese War

\section{Introduction: Seirogan and the Myth of Imperial Benevolence}

If there is any litmus test for measuring the familiarity with Japanese popular culture, Seirogan might be a good one. Looking and tasting 'like charcoal', as a

\footnotetext{
*Email address for correspondence: hekim@tamu.edu
}

I would like to thank four anonymous reviewers whose penetrating and stimulating insights made this article ultimately a better one. Equally helpful were the comments and encouragements by Dale Baum, Donnalee Dox, Ichinokawa Yasutaka, Fukushi Yuki, Iijima Wataru, Kim Youngsoo, Lee Kyung-lock, Nagashima Takeshi, James Rosenheim, Robert Shandley, and Timothy Yang. Librarians and archivists - Itō Kyōko, Haruko Nakamura, Kuniko Yamada McVey, and Matthew Schaefer - helped in the acquisition of essential materials, while Yuki Waugh lent a hand with the Japanese romanisation. This research was financially supported by the Melbern G. Glasscock Center for Humanities Research and the Program to Enhance Scholarly Research and Activities of Texas A\&M University. 
renowned Japanologist recalled, ${ }^{1}$ this soft, pellet-shaped, anti-diarrhoeal herbal medicine is a symbol of katei jōbiyaku (家庭常備薬), a generic over-the-counter pill that any Japanese household stocks and uses to treat minor digestive disturbances in everyday life. ${ }^{2}$ Intimately and unmistakably linked to the idea of travel, Seirogan is currently manufactured by more than thirty different pharmaceutical companies in Japan. Taikō Pharmaceutical's Trumpet Brand - the most famous version - alone sold roughly 41 million bottles of Seirogan (or 2.8 billion yen in sales revenue) from 1995 to 2004, and the pill is now exported to Canada and the United States (US) as well as Korea, Taiwan, and China. ${ }^{3}$ Given the embeddedness of Seirogan in the everyday lives of the Japanese, which can be roughly approximated to the ubiquity of aspirin in western countries, ${ }^{4}$ it is hardly surprising that nationwide consternation erupted between 1998 and 2000 in the wake of the allegation that wood creosotes - the pill's main ingredient - increase the likelihood of liver cancer. ${ }^{5}$

A dependable travel companion for Japanese people, from a middle school student participating in a shūgaku-ryōko (school trip) to a professional flight attendant travelling globally, Seirogan tells us much more than a simple meteoric success story of a welladvertised, over-the-counter drug. What is especially intriguing to historians is the less than subtle way that Seirogan conceals its past, which is as obtrusive as its characteristic odour, in its very name. In Kanji, one of the Japanese writing scripts, Seirogan (正露丸) currently represents 'efficacious-dew-drops' ${ }^{6}$ Before 1949, however, Seirogan (征露丸) had a totally different meaning, and the secret lies in the nature of Kanji and its use of Chinese characters. Ro (露) in Kanji has two different meanings; it means 'dew', but it also refers to 'Russia' as a country. Combined with the Chinese character, sei

\footnotetext{
${ }^{1}$ Donald Keene, Chronicles of My Life: An American in the Heart of Japan (New York: Columbia University Press, 2006), 126.

${ }^{2}$ For instance, in a recent movie, Happy Flight, the heroine Saitō Etsuko (played by Ayase Haruka), a fledgling flight attendant, is embarrassed when her parents give her Seirogan at the Haneda Airport in celebration of and in preparation for her first international flight.

3 'Heisei 17 nen (wa) dai 11663 gō: fusei kyōsō kōi sashitome tō seikyū jiken, [Case Number 11663: A Case for Obtaining an Injunction against Unfair Competition and etc]', 16, available online at http://www.courts.go. jp/hanrei/pdf/20060731093511.pdf (accessed 13 July 2012).

${ }^{4}$ In France, for instance, more than 50 million boxes of aspirin were sold in 1993. C. Florent and N. Mear, 'Epidemiology and Risk Factors for NSAID-induced Gastro-duodenal Accidents', Acta Endoscopica, 28, 4 (1998): 321-5, 324.

${ }^{5}$ Wood creosote, also known as beechwood creosote, is a colourless or yellowish oily liquid mixture of phenolic compounds, produced by the distillation of wood tar. Chemically distinct from coal tar creosote, wood creosote was known for its antiseptic and preservative properties and became popular from the 1830s, especially in Germany. It is believed that wood creosote was first introduced into Japan by Dutch physicians stationed in Nagasaki. See N. Moriguchi et al., 'Moku kureosōto seizai no shiteki hensen (dai ni hō) nippon yakkyokuhō moku kureosōto no kigen ni tsuite [A Historical Review of the Therapeutic Use of Wood Creosote. Part II: Original Plant Source of Crude Drug Wood Creosote]', Yakushigaku Zasshi, 46, 1 (2011), 13-20. In 1998 a group of civil activists, Medwatcher Japan, accused Seirogan of allegedly increasing the possibility of liver cancer through the effects of its main ingredient, wood creosotes. Over the next three years there were intense debates and discussion among civil activist organisations, major manufactures of Seirogan, and the Ministry of the Health, Labour and Welfare. See, for instance, Katō Junichi, 'Seirogan no anzensei niwa, yahari gimon (ronsō) [As to the Safety of Seirogan, There is a Big Question Mark]', Shūkan Kinyōbi, 7, 45 (1999), 64; 'Ishi, bengoshi ga hanbaichūshi yōbōsho, katei no jōbiyaku seirogan wa gekiyaku datta [Doctors and Lawyers Requested the Suspension of Sales; Seirogan was a Deadly Poison!]', Shūkan Gendai, 42,7 (2000), 208-9; 'Shimindantai wa ikisugika!? Kateiyaku Seirogan no kokuhatsu naiyō ni daigimon ari [Did NGOs Go Too Far!? Questions Arise on Complaints]', THEMIS, 9, 4 (2000), 70-1.

6 This is the translation by David Wolff. David Wolff, 'Cultural and Social History on Total War's Global Battlefield', Russian Review, 67, 1 (2008): 70-7, 71.
} 
(征), meaning 'conquer', Seirogan before 1949 meant 'Conquer-Russia-Pill', representing strong hostility against Russia and subsequently against the Soviet Union. Only after 1949, with the guidance of the Ministry of Health and Welfare (Kosei-sho, 厚生省), who feared the potential political fallout of this rather unpleasant designation of an immensely popular medicine, pharmaceutical manufacturers began to use the homonym, sei (正), thus keeping the same pronunciation, but changing the word's meaning radically from a hostile and imperialistic one ('conquer Russia') to an innocuous - even aesthetic - one ('efficacious dew'). ${ }^{7}$

Despite its significance as the symbol of the medicalisation and militarisation of Japanese society in the twentieth century, historians have paid little, if any, attention to Seirogan. A freelance journalist, Machida Shinobu, is probably the most prolific and authoritative writer on the study of Seirogan; his pioneering collection of materials on Seirogan is exemplary, but his analysis of it solely in the context of Japanese traditional medicine does not reflect the larger social and cultural changes of modern Japan. ${ }^{8}$ Tanaka Satoshi superbly analyses the labels and iconography of various Japanese drugs, but his treatment of Seirogan is rudimentary. ${ }^{9}$ When addressing this topic, historians of pharmacy have invariably paid disproportionate attention to the technical aspects of wood creosote. ${ }^{10}$

What professional historians have left as a lacuna has been filled by various urban legends. Originating during the time of the Russo-Japanese War of 1904 and 1905, Seirogan is said to be a pharmaceutical product commissioned by the Meiji Emperor. In preparation for the war, according to one of these legends that made its way even into a newspaper in Korea, the Meiji Emperor allegedly issued an imperial ordinance searching for the ultimate cure for dysentery, which accounted for numerous Japanese deaths during the Sino-Japanese War ten years before. Hundreds of physicians and pharmacists throughout the Japanese archipelago sent their secret remedies. The drug that proved particularly effective against diarrhoea, so we are told, was named Seirogan, the Conquer-Russia-Pill, and has remained a companion of the Japanese people. ${ }^{11}$

Of course this narrative is not entirely true, but it seems convincing and persuasive among the lay public primarily for two reasons. First, it fits nicely into the still prevalent, conventional narrative of the Russo-Japanese War (1904-5); in particular, it jives with the image of the jingoistic rioters who stormed Hibiya Park on 5 September 1905 upon hearing news of the humiliating Treaty of Portsmouth at the close of the Russo-Japanese War, where Japan would receive no outright gains of land, let alone a war indemnity from

\footnotetext{
${ }^{7}$ Akira Suzuki, Denshōyaku no jiten: Gama no abura kara yakuyōshu made [Dictionary of Traditional Medicine] (Tokyo: Tōkyōdō Suppan, 1999), 279-84.

${ }^{8}$ Machida Shinobu, Shōwa retoro shōtengai: rongu serā shōhintachi no shirarezaru hisutorī [Showa Retro Shopping Arcade: Unknown Stories of Long-Sellers] (Tokyo: Hayakawa Shobō, 2006), 21-3.

${ }^{9}$ Tanaka Satoshi, Seirogan no rappa: kusuri no kuni no zuzōgaku [Label of Seirogan: Iconography of the Nation of Pharmaceuticals] (Tokyo: Kawade Shobō Shinsha, 1994).

${ }^{10}$ Baba Tatsuya and Tani Tadato, 'Moku kureosōto to sono shōyaku ganyū seizai no raireki [Wood Creosote: A Historical Study and Its Preparation in Combination with Herbal Drugs]', Yakushigaku zasshi, 36, 1 (2001), 10-17; Moriguchi Nobuaki et al., 'Moku kureosōto seizai no shiteki hensen [A Historical Review of the Therapeutic Use of Wood Creosote Based on its Botanical Origin]', Yakushigaku zasshi, 42, 2 (2007), 110-18; Tomoo Kuge, Takashi Shibata and Michael S. Willett, 'Wood Creosote, the Principal Active Ingredient of Seirogan, an Herbal Antidiarrheal Medicine: A Single-Dose, Dose-Escalation Safety and Pharmacokinetic Study', Pharmacotherapy, 23, 11 (2003), 1391-400.

${ }^{11}$ Im Ho-seop, 'Rŏsia rŭl chŏngbok han Chŏngnohwan [Seirogan that Conquered Russia]', Financial Times, 15 September 2002.
} 
Russia. ${ }^{12}$ Second, it aligns with the interpretation of Japanese imperialism emphasising formal or informal governmental intervention and manipulation. ${ }^{13}$ In other words, as a medical product entrenched in the ideological milieu of wartime Japan, Seirogan seems to illustrate how a medical product was appropriated as an imperial ideological tool in rallying the nationalist spirit of the Japanese people through its medicinal and symbolic efficacy and how the government played a critical role in the process.

But the story is much more complicated than has been suggested or believed, not to mention the lack of documentation substantiating the nationwide competition or an imperial ordinance from the Meiji Emperor. In this article I aim to untangle the process through which Seirogan became deeply entrenched in the everyday life of the Japanese people in the years from 1905 to 1945 . Recognising that pharmaceutical medicine is a medium through which one can achieve a deeper understanding of people's everyday lives in relation to state and society, I maintain that Seirogan reveals unique relationships between the state, emerging commercial manufacturers, and the voracious and patriotic Japanese people. In particular, I argue that it was not the Japanese government that realigned the relationship of the people to the state by enlisting pharmaceutical manufacturers, and thus instilling a sense of militarism in the minds of the ordinary Japanese; rather, it was pharmaceutical manufacturers who took advantage of existing patriotic fervour for their commercial interests and, in the process, reinforced the ideology of militarism on a quotidian level. When the Japanese swallowed the pill, they were not just digesting a highly effective pharmaceutical product, they were consuming a cure for empire.

This pecuniary inculcation and appropriation of patriotic feelings and pride by pharmaceutical companies is evident in the language of contemporary advertisements for Seirogan. Carefully worded and impressively drawn for maximum commercial impact, advertisements in the first half of the twentieth century were 'visual images with normative overtones, a contributor to the society's shared daydreams', as we are told by Roland Marchand with regard to the American case. ${ }^{14}$ And increasingly in the last decade, historians of medicine have emphasised the crucial roles played by pharmaceutical companies, not merely as a thermometer that measured and reflected social and cultural realities, but as a thermostat that actively transformed social imagery and created favourable market conditions. ${ }^{15}$ Nancy Tomes, for instance, emphasised in her Fielding H. Garrison Lecture of 2004 the predominant effectiveness of pharmaceutical advertising and marketing activities in the United States for the past century that simply overpowered the movements of consumer activists and physician reformers in defining medical culture

\footnotetext{
${ }^{12}$ For the changing images of the Russo-Japanese War in Japan, see, for instance, Chiba Isao, 'Shifting Contours of Memory and History, 1904-1980', in David Wolff et al. (eds), The Russo-Japanese War in Global Perspectives: World War Zero Volume II (Leiden: Brill, 2007), 357-78.

${ }^{13}$ See, for instance, Sheldon Garon, Molding Japanese Minds: The State in Everyday Life (Princeton, NJ: Princeton University Press, 1997).

${ }^{14}$ Roland Marchand, Advertising the American Dream: Making Way for Modernity, 1920-1940 (Berkeley: University of California Press, 1986), 232.

15 I borrow the 'thermometer/thermostat' analogy from Martin Luther King Jr., Letter from Birmingham City Jail. The original goes as follows: 'In those days the church was not merely a thermometer that recorded the ideas and principles of popular opinion; it was a thermostat that transformed the mores of society'. Martin Luther King Jr., Letter from Birmingham City Jail (Philadelphia: American Friends Service Committee, 1963), 12.
} 
and policies. ${ }^{16}$ Geographically closer to Japan, Sherman Cochran similarly highlighted the foundational role of 'Chinese Medicine Men' - both Chinese entrepreneurs selling western-style drugs and those selling traditional Chinese medicines - in creating a burgeoning consumer society in China during the first half of the twentieth century through their conscious adoption of various marketing schemes and media, including of course carefully concocted advertisements. ${ }^{17}$

Japan as a maturing nation-state and fledgling empire was no exception to the global ascendance of commercial advertisement as a new source of common vocabulary and to the diligent appropriation of new technologies by pharmaceutical companies. As Susan Burns superbly illustrates in her groundbreaking article, patent medicine advertisements in Meiji and Taishō Japan signified 'visual icons that did more than merely sell the products'. ${ }^{18}$ In trying to carve out their own market in a hostile commercial environment, pharmaceutical manufacturers such as Tsushima Juntendō, Morishita Hiroshi Yakubō, and Yamazaki Teikokudō often amplified and propagated the governmental vision of health, nation, and subjecthood in their advertisements. Yet, as Burns shows us, manufacturers were not merely ventriloquising the official ideology: their messages asserted that 'bodily health can be attained through the market, circumventing the regulatory power of medicine professionals and institutions - and the state that sustained them' ${ }^{19}$

This competing yet complementary relationship between the state and pharmaceutical manufacturers during the Meiji (1868-1912), Taishō (1912-26), and early Shōwa (1926-89) eras is replicated in the advertisements for Seirogan. But before we turn to the colourful and evocative world of advertisement for Seirogan in the 1930s, where the distinctive strategies of Nakajima Pharmaceutical in Osaka transformed the drug into a symbol of empire and patriotism, we first need to tackle the vexing enigma of Seirogan: who were the inventors of the drug?

\section{The Origin of Seirogan during the Russo-Japanese War}

When was Seirogan first manufactured in Japan? This is a rather simple question, but one that has been contested for a long time due to the pill's popularity and obvious commercial potential. Aside from the urban legend recounted in the introduction, there is a claim from the leading manufacturer of Seirogan, the aforementioned Taikō Pharmaceutical from Osaka. According to the official company history, Seirogan was originally introduced in Japan in 1902 when it was manufactured and sold by Nakajima Saichi under the name of Chūyu-Seirogan (忠勇-征露丸: Loyal-and-Brave-Conquer-Russia-Pill). ${ }^{20}$ The company website lists the sales licence issued by the Osaka district office, but does not provide any evidence proving that the sales licence was indeed for Seirogan and that they were the manufacturer who supplied the government with the pills, making the overall claim vulnerable to contestation.

\footnotetext{
${ }^{16}$ Nancy Tomes, 'The Great American Medicine Show Revisited', in Bulletin of the History of Medicine, 79, 4 (2005), 627-63.

${ }^{17}$ Sherman Cochran, Chinese Medicine Men: Consumer Culture in China and Southeast Asia (Cambridge: Harvard University Press, 2006).

${ }^{18}$ Susan L. Burns, 'Marketing health and the modern body: patent medicine advertisements in Meiji-Taishō Japan', in Hans Thomsen and Jennifer Purtle (eds), Looking Modern: East Asian Visual Culture from the Treaty Ports to World War II (Chicago, IL: Art Media Resources, 2009), 173-96.

${ }^{19}$ Ibid., 194.

20 'Seirogan arekore hanashi: seihin hisutorī [This and that about Seirogan: A History of Product].' Available online at http://www.seirogan.co.jp/products/seirogan/various/history.html (accessed 13 July 2012).
} 
The second hypothesis is the one proposed by Machida Shinobu. ${ }^{21}$ In 1903 Totsuka Michitomo (戸塚機知), an army physician and instructor at the Army Medical College, was experimenting with select cultures of typhoid fever and E. coli when he accidentally discovered that creosote was effective in reducing diarrhoea. Totsuka brought this to the attention of one of his students, Shiraiwa Rokurō (白岩六郎), who had been studying bacteriology, and together they created the pill for the use of Japanese soldiers. Machida mentions in his book that he has documentation from the National Diet Library, but he does not specify which documents he consulted.

Given the lack of a smoking gun document that can substantiate the real inventor of Seirogan or kureosōtogan (creosote pill), as it was called within the military, Kasai (or Kawanishi) Kenji (河西健次, 1868-1927) emerges as the most likely candidate. According to Mizokami Kuniyoshi, the editor of the diary of army physician Mizokami Sadao (溝上定男), a participant in the Russo-Japanese War, Kasai was the creator of the pill. A graduate of the Medical Faculty of Tokyo Imperial University and a veteran army physician of the Sino-Japanese War, Kasai helped Totsuka to create a workable pellet called kureosōtogan. ${ }^{22}$ Although Mizokami does not refer back to any primary source, the circumstantial evidence supporting Kasai's candidacy is strong. In 1906 Kasai was ordered to study internal disease in Germany, and at the completion of his two-year research sojourn in Munich, he submitted six theses for a doctoral degree of medicine to Kyoto Imperial University. Of notable interest are two of his theses written in German on the efficacy of creosote as a medicinal ingredient: 'Kureosōto no Chō ni oyobosu Sayō ni tsuite [On the use of creosote on intestines]'; 'Kureosōto no Chiryōteki Ōyō ni tsuite [On the therapeutic application of creosote]'. ${ }^{23}$ It would not be too far-fetched to postulate that Kasai made his name known during the Russo-Japanese War for his work related to the creosote pill and that, for this notable achievement, he was given the honour of studying in Germany with the support of the Ministry of War. His meteoric career after 1908 also strongly supports this hypothesis. In 1908 Kasai, an expert on parasitic diseases, especially schistosomiasis, assumed the position of Chief Sanitation Officer of the South Manchurian Railway Company (Mantetsu), the notorious quasi-governmental spearhead organisation of the Japanese empire in Manchuria, where he stayed until he eventually rose to become the first president of the Medical College of South Manchuria. ${ }^{24}$

If the creosote pill was the invention of this army physician, when was Seirogan first introduced to the soldiers in the battlefields in Manchuria? The detailed day-to-day diary of army staff physician Mizokami Sadao evinces that, on 27 April 1904, kureosōtogan was distributed for the first time, two and a half months after the onset of the war. ${ }^{25}$ Later, in the entry of 28 May 1905, Mizokami includes a report of dysentery pill consumption in the month of May. ${ }^{26}$ Among the 170 soldiers in the third company, 145 consumed entire doses while twenty of them took two-thirds and five of them took only one-third of the allocated doses. What is interesting in this entry is that the name of the pill has been changed from kureosōtogan to Seirogan in the meantime. Machida claims that the

\footnotetext{
${ }^{21}$ Machida Shinobu, Makkāsā to seirogan: nippon dentōyaku monogatari [MacArthur and Seirogan: A Story of Japanese Traditional Medicine] (Tokyo: Geibunsha, 1997), 17-18.

${ }^{22}$ Mizokami Sadao, in Mizokami Kuniyoshi (ed.), Nichi-Ro Sensō jūgunki: gun’i no jinchū nikki [A Testimony of the Russo-Japanese War: Diary of Army Physician] (Kyoto: Shinbunkaku Shuppan, 2004), 150.

${ }^{23}$ Who's Who Hakushi in Great Japan (1922), 107-8.

${ }^{24}$ Manshū Nihonjin meikan [Register of Notables in Manchuria] (1915), 251.

${ }^{25}$ Mizokami, op. cit. (note 22), 39-40.

${ }^{26}$ Mizokami, op. cit. (note 22), 127.
} 
pill's official designation remained kureosōtogan through the end of the war, but the diary of Mizokami claims otherwise, ${ }^{27}$ which is confirmed by the imperial army's own supplementary expense report demonstrating that, as early as June 1904, the pill was called Seirogan. $^{28}$

Also significant to our discussion of Seirogan along with the issue of its inventor and adopted name is that its extensive use from 1904 was noticed even by outside observers from Europe. Quoting the magazine Chemist and Druggist as its source, the Times of London reported on 19 November 1904 'one of the heaviest ... consumptions of drugs and medicines in the war' in the article titled 'Japanese War Drugs':

At least 50,000 cases of medicines and medical requisites have been shipped from Japan to the port of Dalny, whence they are distributed among the troops in Manchuria... Beechwood creosote is one of the most interesting articles in use; it is supposed to prevent dysentery, which is very prevalent in Manchuria, and the medical department decided to give each soldier a pill containing 0.25 creosote at a meal, or three pills a day. Each soldier's requirements are nicely packed in small tins, each containing 90 pills, or a month's supply; they are labelled 'Russian Expedition Pills'. At the busiest time 2,000,000 pills a day were made by the army's tablet and pill works in Tokio. During February the Government bought all the available stocks of creosote, and consequently the price has advanced from 1.50 yen per pound (the normal market price) to 4 yen! ${ }^{29}$

The production of Seirogan in the army's own tablet and pill factory discredits the claim by Taikō Pharmaceutical that they (or their predecessor, Nakajima Pharmaceutical) were the manufacturers of the army supplies. What is even more remarkable is the sheer volume of the pill $-2,000,000$ pills a day, which was equal to a daily supply of three pills to over 700,000 soldiers - and the nearly tripled price of creosote in the global market. Why did the Japanese army need this inordinate amount of pills? In other words, how serious was the damage from dysentery and related diseases for the Japanese army?

The Japanese army had struggled with diseases such as dysentery, typhoid fever, and beriberi (Kakke in Japanese) ever since Meiji Japan introduced universal conscription in 1872 and started building up its military capacity. ${ }^{30}$ During the Sino-Japanese War of 1894-5, for instance, the Japanese army lost a total of 13,488 soldiers. Only 1,594 died in active combat on the front lines; the remaining 11,894 soldiers, or eighty-eight per cent, died from sickness. ${ }^{31}$ The situation improved slightly in the Boxer Rebellion of 1900 in China - 949 out of 1,306 , or seventy-two per cent, died from diseases, ${ }^{32}$ but the fatality rate was still alarming to the Japanese army leaders who were to shoulder the task of expansion into Manchuria and eventually into the Chinese mainland. ${ }^{33}$

27 Machida, op. cit. (note 21), 34.

28 'Eisei zairyō shō ni oite dōin wo tomonau keihi tsuika no ken [A report on the expenses et. al on securing hygienic materials]', Japan Center for Asian Historical Records, Ref. C03025693800, Meiji 37, Mandai nikki, 6/1-6/15 (National Institute for Defense Studies), 2.

${ }^{29}$ The Times of London, 19 November 1904, 12

${ }^{30}$ Alan Hawk, 'The Great Disease Enemy, Kak'ke (Beriberi) and the Imperial Japanese Army', Military Medicine, 171, 4 (2006), 333-9.

${ }^{31}$ Hara Takeshi and Yasuoka Akio (eds), Nihon Riku-Kaigun jiten [Dictionary of Army and Navy] (Tokyo: Shin Jinbutsu Oraisha, 1997), 498.

32 Ibid..

33 Japan was not an exception to the global trend. In the American-Spanish War of 1898, fourteen men died as a result of disease for every one man killed in battle. Alfred Bollet, 'Military Medicine in the Spanish-American War', Perspectives of Biology and Medicine, 48, 2 (2005), 293-300. One of the most startling was the French campaign in Madagascar of 1894 where 14,000 men were sent to the front, of whom twenty-nine were killed in action, while 7,000 died from preventable disease. Louise L. Seaman, The Real Triumph of Japan: The Conquest of the Silent Foe (New York: D. Appleton and Company, 1906), 3. 
There was no question that something had to be done. Thankfully, the return of a cohort of military-sponsored physicians from Germany in the late 1880s and early 1890s provided the Japanese government with sorely needed experts. With Mori Rintarō (better known by his pen name, Mori Ōgai, and his eventual position as Army Surgeon-General) as the most renowned example of this cohort, these military physicians, who had been exposed to cutting-edge hygiene and bacteriology in Berlin and Munich, were determined to fight the disease enemy from multiple angles. On one hand, the military adopted various preventive measures, such as the modernisation of the rationing system, the improvement of the hygienic situation in the barracks, and the provision of a clean potable water system. On the other hand, military medical personnel strove to provide curative methods to treat diseases, and Seirogan was developed in this context.

While the vanity of Germany-educated bacteriologists sometimes had a disastrous impact on the lives of the Japanese soldiers - for instance, Ogata Masanori and Mori Rintarō firmly believed that beriberi was caused by germs, disputing Takaki Kanehiro's idea that the cause of beriberi would be found in a diet based on white rice ${ }^{34}-$ the combination of preventive and curative measures dramatically reduced fatality from diseases. Of the 84,435 army soldiers who died in the Russo-Japanese War, only 23,093 or twenty-seven per cent died from sickness. ${ }^{35}$ In other words, the fatality rate from diseases dropped from eighty-eight per cent to twenty-seven per cent in the short span of ten years.

This notable achievement was striking enough for Louis Livingstone Seaman, an American surgeon-major, to dedicate his 1906 book, The Real Triumph of Japan: The Conquest of the Silent Foe, to the medical and sanitary officers of the Japanese army. As a foreign military attaché to the Second Imperial Army of Japan on the Mongolian frontier during the Russo-Japanese War, Seaman witnessed how cutting-edge hygienic medical facilities and techniques - such as a state-of-the-art water-testing outfit, microscopes, and a portable X-ray apparatus - were working seamlessly in the Japanese army. As a result of this innovation, Seaman observes, 'Malaria is malaria and typhoid is typhoid in the Japanese Army, and not "Fever", caused by inappropriate and irritating rations, because every case there is differentiated under the microscope and otherwise. Diseases are not guessed at'. ${ }^{36}$

Just as a foreign observer was inspired by the medical prowess of Japanese army physicians and their medicinal products, at the close of the war returning Japanese soldiers brought home stories of their stunning victories over the Russians along with stories of Seirogan. Among them, the most famous - though unsubstantiated - was the story of peasants in Manchuria who were willing to give up a chicken for a single pellet of Seirogan. ${ }^{37}$ Nishimura, the author of the Gun'i no mitaru nichiro sensō of 1934, introduces yet another story in which a local resident in the Hida (飛騨) region voluntarily gave his Seirogan that he himself had saved for many years after his service in Manchuria to a

\footnotetext{
${ }^{34}$ For details regarding this controversy, see Christian Oberländer, 'The Rise of Scientific Medicine in Japan: Beriberi as the Driving Force in the Quest for Specific Causes and the Introduction of Bacteriology', Historia Scientiarum: International Journal of the History of Science Society of Japan, 13, 3 (2004), 176-99; idem, 'The rise of western 'scientific medicine' in Japan: bacteriology and beriberi', in Morris Low (ed.), Building a Modern Japan: Science, Technology, and Medicine in the Meiji Era and Beyond (New York: Palgrave Macmillan, 2005): 13-36.

35 Hara and Yasuoka, op. cit. (note 31), 498.

36 Seaman, op. cit. (note 33), 12.

${ }^{37}$ Machida, op. cit. (note 21), 20.
} 
dying visitor to his village. ${ }^{38}$ Imbued with a mythic aura, Seirogan, the cure for empire, finally came home.

\section{Capitalising on Patriotic Fervour: Seirogan in Late Meiji and Taishō Japan}

It has often been believed that the victory of Japan over Russia - the first defeat of a European power by non-Europeans - intensified a sense of belonging among the Japanese people while elevating the status of the military in the society and minds of the Japanese. ${ }^{39}$ This narrative of enthusiastic popular nationalism instilled and fuelled by the war, however, has recently been challenged by a new interpretation that emphasises the plurality and diversity of Japanese society before, during, and after the war. Most notably, Naoko Shimazu, with her careful analysis of private materials such as diaries of Japanese conscripts and her emphasis on local dimensions of wartime mobilisation and commemoration, argues that the wartime Japanese society of 1904-5 was anything but a unified society of fervent patriots under the direct guidance of a strong central government; instead, it was a war-weary and ambivalent populace. Of course, Shimazu does not necessarily believe that all of the Japanese were despondent. If anything,

some segments of society were vociferously patriotic, such as the pro-war factions, the commercial sector (including the media) which saw war as a lucrative bedfellow, as well as those (mostly in the middle classes) in society who could afford to partake in the patriotic bubble of the wartime economy. ${ }^{40}$

Japanese pharmaceutical manufacturers were one of such commercial opportunists who lost no time in capitalising on the patriotic fervour. ${ }^{41}$ An advertisement for Seiro (セイロ), a product of pharmaceutical manufacturer Hirose-shōten (広瀬商店) from 1906, is a clear example of this trend (Figure 1). ${ }^{42}$

A proud army officer is holding the Kyokujitsu-ki, the flag of the Japanese imperial army and navy, and the glorious laurel of Seiro. To his right, one finds a quick description of the origin of this drug with important keywords highlighted in block letters: at the time of the Russo-Japanese War, the Japanese government bestowed largess (400,000 yen) upon the Army Surgeon Commander and the Army Surgeon-General; with that money, the army created a group of thirty-six pharmacologists who invented the drug. Its efficacy? 'Ask a million veterans', says the advertisement. The advertisement does not stop at touting the army's achievement and the company's alleged connection to the military. 'If you do not know this pill', warns the caption, 'you are not a Japanese citizen'. The final finesse is a classic lie of a merchant: 'this drug is not for commercial profit; it is to celebrate and remember the glorious victory'. Who would dare to refuse such a noble product? Purchase of this drug was after all tantamount to the confirmation of one's sense of belonging and loyalty to the state.

Similar to Seiro in its use of a uniformed man, Ganso Seirogan ('Original ConquerRussia-Pill') from Nippon Iyakuhin Seizō, played the card of authenticity - this is 'original' - when the company introduced its product in 1909. To ward off rivals and to give the impression of genuineness, Ganso Seirogan incorporated a picture of an elderly

\footnotetext{
${ }^{38}$ Nishimura Fumio, Gun'i no mitaru nichiro sensō (Tokyo, 1934). Quoted in Machida, op. cit. (note 21), 20.

${ }^{39}$ Marius B. Jansen, The Making of Modern Japan (Cambridge, MA: Harvard University Press, 2002), 452.

${ }^{40}$ Naoko Shimazu, Japanese Society at War: Death, Memory and the Russo-Japanese War (Cambridge: Cambridge University Press, 2009), 53.

${ }^{41}$ Suzuki Akira, Nihon no denshōyaku: Edo baiyaku kara kateiyaku made [Japanese Traditional Drugs: From Edo Patent Medicine to Everyday Drugs] (Tokyo: Yakuji Nipposha, 2005), 233.

42 Machida Shinobu kindly informed me of the exact citation of this image, for which I am grateful.
} 


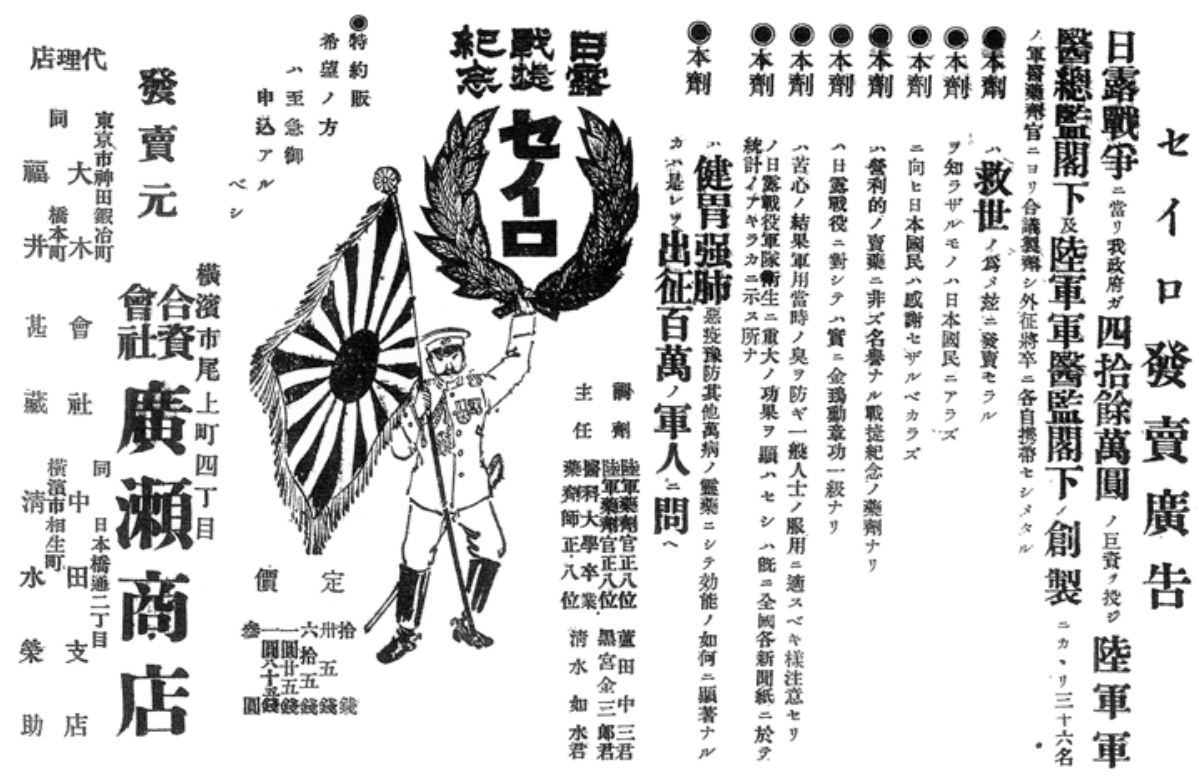

Figure 1: Yakugyō jihō, 1 November 1906.

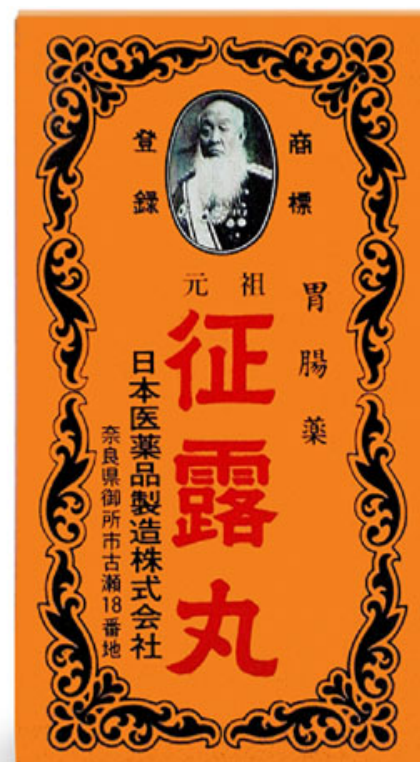

Figure 2: Ganso Seirogan. Current packaging. Source: Nippon Iyakuhin Seizō. Used with permission. 
gentleman with a long white beard - Matsumoto Jun (松本順, 1832-1907), the first Army Surgeon-General of Meiji Japan (Figure 2). To the company, Matsumoto was the perfect spokesperson for two reasons. On one hand, as the first Army Surgeon-General and as part of the very first generation of Japanese physicians who had been educated with western medical science in Nagasaki, Matsumoto bespoke the genesis of modern medical science and its products in Japan. Simultaneously, dressed in military uniform and endowed with a long beard, his physical appearance corporealised the authenticity of Ganso Seirogan. The fact that Matsumoto was in office from 1873 to 1879 and therefore had nothing to do with the development of Seirogan was simply ignored.

The relatively simple process of concocting this anti-diarrhoeal pill enticed even a hardcore revolutionary activist into the market of Seirogan. Kimoto Bonjin (木本凡人, 1888-1947), a famous anarchist and one of the founding members of the antiestablishment society suiheisha (Organisation of Levellers), began manufacturing and selling Seirogan in his house in $1920 .{ }^{43}$ Educated at Osaka Dental School (Osaka Shika Igaku Senmon Gakkō, now Osaka Dental University), Kimoto must have possessed a workable level of pharmacological knowledge and put this into use to raise money for the cause of egalitarianism. His venture was commercially viable until his production and sale of the drug was put under strict governmental control in 1941, apparently due to his political orientation. However, Kimoto's pharmaceutical business put bread on the table for his family for over twenty years. ${ }^{4}$

The irony of an anarchist making a living by selling a Conquer-Russia-Pill might give the impression that there was a surge of interest in the drug during or immediately after the Russo-Japanese War. In contrast to what some historians have long argued, however, no major newspapers and magazines, such as Tokyo Puck, which was saturated with patent medicine advertisements, ever advertised Seirogan in the 1910 s. ${ }^{45}$ Given this strange absence of Seirogan in the major venues of commercial advertisements, one might be tempted to claim that the extreme popularity and name recognition of Seirogan made it unnecessary to advertise it broadly during much of the 1910s and the first half of the 1920s. But the reality was that the name Seirogan was not ingrained in the world of pharmaceutical manufacturers, not to mention the minds of the Japanese people who had already lost interest in remembering the Russo-Japanese War in the era of Taishō democracy (1912-26). ${ }^{46}$ For instance, Nihon Meiyaku Ichiran, a registry of the most famous drugs in Japan published in 1934, lists over 480 pharmaceutical products, but does not include Seirogan in its extensive list. ${ }^{47}$

\footnotetext{
43 Nihon Anakizumu Undō Jiten Henshu linkai, Nihon Anakizumu Undō Jinmei Jiten [Dictionary of Japanese Anarchist Movement] (Tokyo: Paru Shuppan, 2004), 212.

${ }^{44}$ Miyazaki Akira, 'Kimoto Bonjin to, Ana kei mikaihō buraku undō no taidō [Kimoto Bonjin and the birth of the Burakumin rights movement of anarchists group]', in Sabetsu to Anakizumu: Suiheisha undō to ana-boru kōsōshi [Discrimination and Anarchism: Suiheisha Movement and a History of Anarchism-Bolshevism Conflict] (Iseizaki: Kokushoku sensen sha, 1975), 10-11.

${ }^{45}$ For instance, Yulia Mikhailova claims in her article, 'Japan and Russia: mutual images, 1904-1939', that 'Newspapers and magazines widely advertised the medicine "seirogan", a stomach pain-reliever, substituting the character "sei" (justice) for "sei" (overcome), thus turning its meaning into "subjugation of Russia". Yulia Mikhailova, 'Japan and Russia: mutual images, 1904-1939', in Bert Edström (ed.), The Japanese and Europe: Images and Perceptions (Richmond: Curzon Press, 2000), 152-72.

46 Shimazu, op. cit. (note 40), 230.

47 Meiyaku Chōsakai, Nihon Meiyaku Ichiran [A List of Japan's Best Medicines] (Tokyo: Nihon Meiyaku Ichiran Kankokai, 1934).
} 
In this respect, the rise of Seirogan to the level of a nationally renowned medical product was the work of Nakajima Saichi Drugstore which, in recognising the changing geopolitical situation of the 1930s, mobilised the power of the advertisement and cleverly appropriated the potential of the military image for the benefit of its own commercial success.

\section{Nakajima Drugstore, Seirogan, and the Making of Patriotic Japanese}

Little is known about Nakajima Drugstore or its owner Nakajima Saichi, except that he was based in Osaka, the traditional epicentre of pharmaceutical production and distribution since the Tokugawa era (1600-1868). But there should be no contention that Nakajima Drugstore initiated the advertising campaign of Seirogan and in the process indelibly imprinted the brand and image of Seirogan in the minds of the Japanese people. In fact, until 1923, when the first national advertisement of the Nakajima Drugstore's $C h \bar{u} y \bar{u}$ Seirogan (Loyal-and-Brave-Conquer-Russia-Pill) was featured in Yomiuri Shinbun, a Japanese newspaper, there was no significant advertisement campaigning of Seirogan (Figure 3).

Neither did the advertisement immediately develop into a full-scale bombardment of newspapers and magazines with images of Seirogan. Between 1923 and 1925, Nakajima Drugstore briefly tried advertising with the Tokyo-based Yomiuri Shinbun, but it was merely experimental; there was only one advertisement in 1923 (24 December), four in 1924, and six in 1925. Moreover, instead of helping Nakajima Drugstore to gain recognition among Japanese consumers, this early phase of advertising that patently failed to reflect the pulse of the society almost cost Nakajima Drugstore its entire business of manufacturing and selling Seirogan. On 19 October 1925 the embassy of the Soviet Union in Tokyo sent a strongly worded request to the Ministry of Foreign Affairs of Japan, asking them to pay attention to the advertisement published in Yomiuri Shinbun and to take measures to stop such a campaign. 'The advertisement text notes that the "Seirogan of Nakajima" means "expedition against Russia", or "Down with Russia", or something similar'. The letter argues in a very diplomatic way that 'the publication of such claim and the very fact that such a name is given to a merchandise of any kind is contrary to the condition of the normal relations established between the two countries'. ${ }^{48}$

Faced with this acerbic reaction from the Soviet Union, the Ministry of the Foreign Affairs of Japan in turn mobilised administrative power to block such advertisements. Not only did the Ministry alert the Bureau of Patents so that, on 6 January 1926 the registration of the trademark of Nakajima's Chüyu-Seirogan was cancelled on the grounds that it was against international customs and public order, it also made sure that the decision was confirmed in a court ruling on 28 June. In a response sent to the Soviet Embassy on 15 November 1926, almost a year after the initial request from the Soviet side, therefore, the ministry could proudly claim that it had solved the matter permanently and even included as evidence a copy of the advertisement of another former Seirogan manufacturer (published in Osaka Asahi Shinbun on 19 October 1926) who cleverly registered the trademark of Shinrogan (Befriending-Russia-Pill). ${ }^{49}$

\footnotetext{
48 'Baiyaku Seirogan no shōhyō ni kansuru ken Taishō 14-nen 10-gatsu [A Case on the Trademark of a Patent Medicine, Seirogan]', Japan Centre for Asian Historical Records, Ref. B11091584800 (The Diplomatic Record Office of the Foreign Affairs), 4.

${ }^{49}$ Ibid., 13; 20.
} 


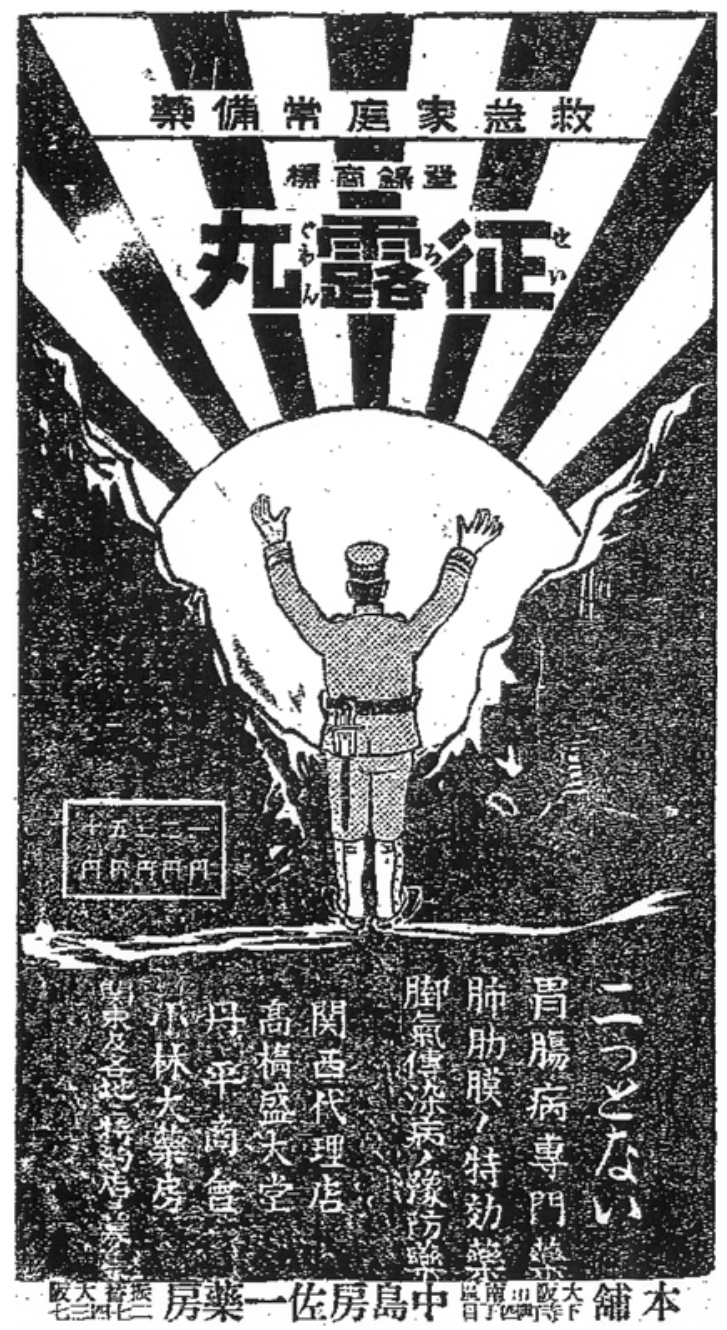

Figure 3: Yomiuri Shinbun, 24 December 1923.

The Russians might have been satisfied with this solution, but it was not the end of Chūyu-Seirogan, let alone the term Seirogan. Unlike what the Ministry of Foreign Affairs insinuated to the Soviet embassy, the court ruling of 28 June did not prohibit the manufacturing and selling of the drug itself; rather, what it specified was the cancellation of the trademark only, based on the fact that Seirogan was a commonly accepted name, thus ironically making the name Seirogan available to anyone. Nakajima Drugstore did not, however, resume its marketing campaign immediately after the unintended acquiescence of the government. On the one hand, it was prudent for them to wait until the dust settled. But, more significantly, they must have realised (rather belatedly) that with the overall social sentiment of the Taishō period, with its emblematic dedication to democracy and internationalism, it was not favourable for them to market a drug that was based solely upon the mythic image of Japanese soldiers during the war that had ended twenty years earlier. 
The voluntary (or maybe involuntary) marketing hiatus did not last long, though. In September 1931 the infamous Manchurian Incident, which would eventually usher in the so-called Fifteen-Year War (from 1931 to the surrender of Japan on 15 August 1945) in Asia, broke out and a discussion about it subsequently flooded the Japanese media. What changed was the government view of the Russo-Japanese War. In a new geopolitical situation where the notion of war became relevant and imminent to Japan as a whole, the state found the victory of the Russo-Japanese War a reusable historical asset that could rekindle popular enthusiasm for military conquest in Manchuria. Enabling the state to achieve this task was what historian Shimazu calls the 'commemoration industry', a certain commercial sector that acutely recognised and was determined to capitalise on the wind of social and market change blowing through Japan and Asia through pageantry, exhibitions, and films. This 'commemoration industry' functioned as 'the principal vehicle for popularizing the memory of the Russo-Japanese War in the 1930s' ${ }^{50}$

At this new historical juncture where the memory of the Russo-Japanese War was being resurrected from the dustbin of history, Nakajima Drugstore lost no time in taking advantage of the changing geopolitical and domestic situation and immediately resumed its advertising campaign of Seirogan in Osaka Asahi Shinbun, the leading newspaper of the Kansai region, in September 1931. The pace of the still-sporadic marketing efforts of the early 1930s accelerated to full speed in 1937 with the outbreak of the second SinoJapanese War in China. In 1938 there were thirty-eight listings with Osaka Asahi Shinbun, evenly distributed throughout the year, and Nakajima Drugstore kept a similar frequency until 1941, when it added Tokyo Asahi Shinbun as well and ran thirty advertisements with it in 1941 alone.

Admittedly, the absolute number of the advertisements from 1937 to 1941 may seem to indicate that the inundation of images of Seirogan in Japanese newspapers is an exaggeration. Even at the height of the advertisement spree, Nakajima Drugstore could only run the advertisement once or twice a week. But the effectiveness of the Nakajima advertisements resided not in their frequency but, rather, in three distinctive and innovative features: the appropriation of the authority of the military, the extensive use of explicit illustrations, and the re-interpretation of overarching wartime ideologies. These aspects made the drug resonate uniquely with the Japanese public who were now more receptive to and familiar with militaristic imagery than ever before.

In its advertisements, first and foremost, Nakajima Drugstore broke from the convention of using authoritative figures in the sales of patent medicine. Just as they do today, medical doctors frequently appeared in drug advertisements to affirm the medical efficacy of pharmaceutical products, and modern Japan was not immune to this tried-and-proven tactic. Berutsu-gan, a patent medicine of Suzuki Nippon-Seiyakusha of Tokyo, is one such example that relied almost exclusively on the fame of doctors. In the advertisement that appeared on 8 April 1938 in Osaka Asahi Shinbun, Suzuki Nippon-Seiyakusha used Erwin Baelz, arguably the most well-known German doctor in Japan who taught at Tokyo Imperial University over a quarter century (1876-1902) and had been a court physician to the Japanese imperial household, to make this cure-all drug appear authentic (Figure 4). Of course, Nippon-Seiyakusha did not reveal in the advertisement that Baelz had passed away in 1913 and could not possibly have given permission to the company to use his transliterated name in Japanese (Berutsu) as the brand of a 'miracle drug' that allegedly

${ }^{50}$ Shimazu, op. cit (note 40), 231. 


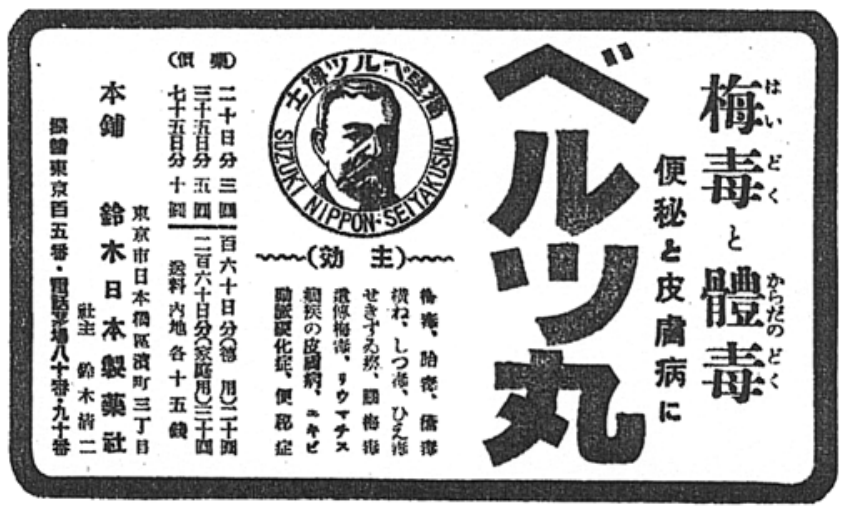

Figure 4: Osaka Asahi Shinbun, 8 April 1938.

cured such diverse diseases and symptoms as syphilis, intoxication, constipation, and general fatigue.

Instead, Nakajima Drugstore elevated this tradition of using external authority to a whole new level by appropriating the ultimate authority available in Japan - the imperial army and navy, and by extension, the Emperor of Japan himself. All advertisements of Seirogan included the notice 'rikukaikū goyō yaku' ('a drug adopted and consumed by the Imperial Army, Navy, and Air Force'). In the main body of the advertisement, one could almost always find blatantly self-congratulatory text giving the aura of historical authenticity.

Not only has this drug served our imperial army for over thirty years since the Russo-Japanese War, it has been adopted and endorsed in abundant quantities by many quarters since the recent Manchurian Incident and the second Sino-Japanese War. All those who fight on the home front should take this opportunity to keep this drug on hand and recognise its medical efficacy. ${ }^{51}$

This strategy of inventing tradition as a way to concoct an alleged connection with the military was visually enhanced by the extensive use of explicit images of soldiers on duty. From a young recruit beaming with a bright smile with Seirogan in his right hand to a soldier out on patrol on a snowy night, soldiers of the Japanese imperial army, faithful to their duties throughout the four seasons, were prominently featured in the advertisements of Nakajima Drugstore. A navy sailor in his emblematic white uniform and a fighter jet flying over the Japanese archipelago were also mobilised in graphics to attract the attention of Japanese consumers.

More importantly, Nakajima Drugstore actively rehashed, reformulated, and reintroduced contemporary wartime ideology, using readily available and widely understood symbols and icons. In the process, of course, Nakajima Drugstore did not forget to cleverly ensconce their commercial interests in the languages of anticommunism, condescension towards China, and the New Order System. In short, Nakajima Drugstore was a commercial ventriloquist of wartime propaganda.

Drawn from a reservoir of familiar images and symbols of anti-Russianism, anticommunism was the most easily discernible message conveyed in the advertisements of Seirogan. As Michiko Ikuta noted in her article, as early as the late Tokugawa era

51 Osaka Asahi Shinbun, 10 November 1938. 


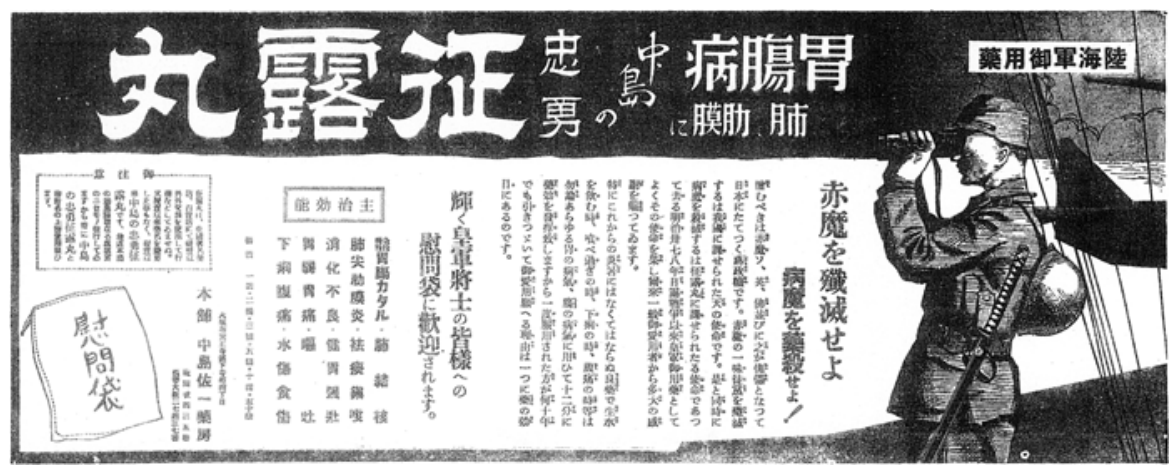

Figure 5: Osaka Asahi Shinbun, July 20, 1939.

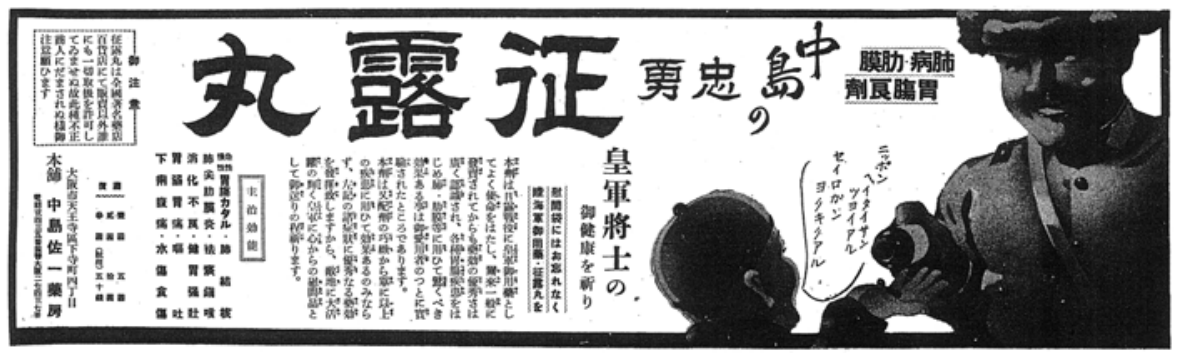

Figure 6: Osaka Asahi Shinbun, 17 February 1937.

(1600-1868), perceptions of Russia in Japan were anything but positive; whereas the Dutch and other Europeans were perceived in light of their religious and intellectual challenges, Russians, due to their geographical proximity to Japan, were predominantly portrayed as menacing intruders. ${ }^{52}$ This negative image of Russia was further amplified and reinforced during the course of the Russo-Japanese War. In the process of creating and propagating a favourable image of Japan both within and without the Japanese archipelago, the Japanese authorities, often with the explicit support of American and British press, successfully demonised their enemy. ${ }^{53}$ The subsequent Sovietisation of Russia further denigrated the image of Russia among the Japanese. And the Nakajima Drugstore did not hesitate to co-opt the widely recognised image of the Soviet demon. As is seen in the advertisement posted in Osaka Asahi Shinbun on 20 July 1939, communism personified by the Soviet Union was a 'red demon' (aka-ma in Japanese) that Japan was 'heavenly mandated' to destroy (Figure 5). Rhyming with the call for action against communism was the exhortation to destroy the 'disease demon' (byō-ma) by using a drug, Seirogan. The comparison cannot be misunderstood - just as imperial Japan was destined to destroy the 'red demon', Seirogan was invented to kill the 'disease demon'.

\footnotetext{
52 Michiko Ikuta, 'Changing Japanese-Russian images in the Edo period', in Yulia Mikhailova and M. William Steele (eds), Japan and Russia: Three Centuries of Mutual Images (Kent: Global Oriental, 2008), 11-31: 27.

53 See Rotem Kowner, 'Japan's "Fifteen Minutes of Glory": Managing World Opinion During the War with Russia, 1904-5', in Mikhailova and Steele (eds), ibid., 48-70.
} 
Along with fervent anti-communism, a strong condescension toward China was a recurring theme of advertisements for Seirogan that any Japanese could easily decipher the meaning of. A tall Japanese soldier was typically juxtaposed with a Chinese child, usually a girl, holding the child by the hand, carrying him or her on his back, or patting him or her on the head. Most prevalent, however, was the image of a Japanese soldier offering Seirogan to a needy and eager Chinese child. The advertisement of 17 February 1937, with the title 'Praying for the health of strong imperial soldiers' is one such example (Figure 6). Here, a Japanese soldier with a smile is handing out pellets of Seirogan to a Chinese child, whose head and right hand only appear in the bottom half of the advertisement. The child is speaking to the Japanese soldier in broken Japanese: 'Japan, soldier, strong. Seirogan. Heard a lot'. The implication is unmistakable. Japan as an imperial power needs to help China, an immature society, and the easiest thing to do to respond to this call of duty is to purchase Seirogan, an undeniable symbol of Japanese vitality.

The most outlandish attempt to appropriate the wartime ideology was Nakajima Drugstore's invention of the slogan, 'New Order of Health' (Kenkō no shintaisei) in parallel to the government's New Order System (shintaisei). As is well documented by historians, the New Order movement from 1938 was designed to reintegrate the Japanese people into the well-oiled machine of wartime imperialism. ${ }^{54}$ Using the concept of a New Order of Health, the Nakajima Drugstore encouraged the Japanese to consider not only their attitudes in relation to their own bodies, but also toward the government and its soldiers, a refashioning that Nakajima Drugstore was ready to commercially exploit.

The advertisement of 2 November 1940 in this respect is exceptional both in its form and content (Figure 7). Moving away from the usual reliance on explicit images of masculine soldiers, this advertising piece titled 'New Order of My Life' (boku no seikatsu shintaisei) takes the form of an eight-panel comic illustrating an exemplary everyday life under the New Order that every Japanese person should strive to follow. The comic starts with the daily practice of 'paying respect at the Shinto Shrine'. Then, the male protagonist 'resolutely goes to work on foot'. Lunch is of course a 'substitute food', and he does not forget to remind his colleague that 'today is a non-smoking day'. Thinking of the war front, he pushes himself to work harder. Then, home after work, he thinks 'um... it seems like I forgot to do something...' when he hears, 'Please take a look at this, Daddy', a timely reminder from his son who is holding a letter saying 'thank you, soldiers'. 'Yes, I've been meaning to send a comfort kit (imonbukuro) to the front'. The advertisement ends with a scene of mom, dad, and son all smiling while putting Seirogan into a comfort kit. As with other advertisements from Nakajima Drugstore, the message does not require even a moment of deliberation - not only does Seirogan signify the culmination and completion of the daily activities under the rubric of the New Order movement, it also functions as a medium that links the home front to the battlefield, thus providing a space for Japanese consumers to contribute to and associate themselves with the war efforts.

As historian Marchand argues, 'advertisements were secular sermons, exhortations to seek fulfilment through the consumption of materials goods'. ${ }^{55}$ And as secular sermons preached during wartime Japan, the advertisements of Nakajima Drugstore's Seirogan extolled the consumption of this anti-diarrhoeal pill as the faithful fulfilment of the patriotic duty of imperial subjects. But questions still remain. How successful was the advertising campaign? Did Japanese consumers actively respond to the patriotic yet

${ }^{54}$ See, for instance, Ben-Ami Shillony, Politics and Culture in Wartime Japan (Oxford: Clarendon Press, 1981).

55 Marchand, op. cit. (note 14), 264. 


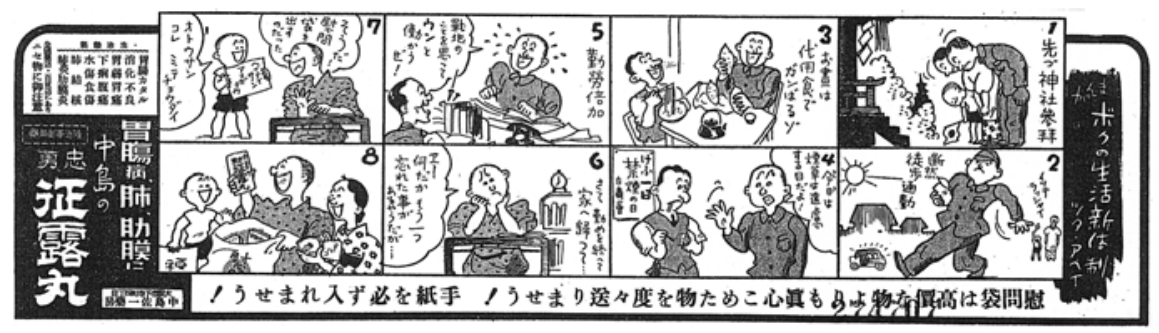

Figure 7: Osaka Asahi Shinbun, 2 November 1940.

commercial exhortations? Unfortunately, there are no official sales figures available from the 1930s and the first half of the 1940s, but we can ascertain the enduring success of the drug from circumstantial evidence.

First of all, in 1949, as previously mentioned in the introduction, the Japanese government, in consideration of its fragile relations with the Soviet Union, ordered manufacturers of Seirogan to change the Kanji character that corresponds to 'sei' from 'conquer' to 'righteousness'. With no request from the Soviet Union, as was the case in 1925, this decision by the Licensing Department of the Ministry of Health and Welfare was most likely a proactive effort to 'demilitarise' the popular over-the-counter drug that had gained a wider consumer base through the wartime period. On a related note, the administrative guidance that required all manufacturers to change the Kanji character only, not the actual name of Seirogan itself, should be interpreted as reflecting the embeddedness of Seirogan in the minds of Japanese consumers.

Furthermore, the vehement opposition from small-scale manufacturers of Seirogan against the attempt of Taikō Pharmaceutical to register the name of Seirogan with a new Kanji character as a trademark evinces the commercial success or at least the commercial viability of Seirogan in the transwar years. As previously explained, Taikō Pharmaceutical is the successor of the Nakajima Drugstore. Shibata Otojirō, who founded Shibata Pharmacy in 1940, acquired the sales rights for Chūyū Seirogan from Nakajima Drugstore in April 1946 and subsequently changed the name of his company to Taikō Pharmaceutical in November of the same year. In 1949, likely following the administrative guidance of the Ministry of Health and Welfare, Taikō Pharmaceutical changed the name of its flagship drug Chūyu Seirogan to Nakajima Seirogan (with a new Kanji), and then, in November 1954, registered Seirogan as a trademark. In response to this effort to monopolise the over-the-counter anti-diarrhoeal product, a group of small pharmamanufacturers formed the National Coalition for the Free Use of Seirogan (Seirogan jiyū shiyō kantetsu zenkoku dōmeikai) and strongly argued that Seirogan should not be monopolised by a single company because it was originally invented by the imperial army and the name had become a common noun rather than a brand. ${ }^{56}$ The fierce legal battle that engulfed the Japanese pharmaceutical world in the 1950s and 1960s came to an end only in March 1974 when the Japanese Supreme Court declared that Seirogan is a common noun and thus cannot be used as a trademark. ${ }^{57}$

The postwar contention over the use of the name Seirogan unmistakably indicates that this stomach pill had rooted itself deeply into the minds of the Japanese people in the 1930s and 1940s. And this imprint was mostly the result of the advertising campaign

\footnotetext{
56 Yakuji Nippō, 11 June 1955, 2.

57 Sumiko Oshima, 'New Miracles from the "First Miracle Drug”, Japan Times Online, 15 January 2001. http://info.japantimes.co.jp/text/fl20010115a1.html (accessed 25 January 2013).
} 
of Nakajima Drugstore, which took advantage of the changing geopolitical situation in East Asia and the rise of militarism in Japan from 1931. By riding upon the image of the imperial army, using explicit graphics, and cleverly appropriating the official ideology of the wartime period in its advertisements, Nakajima Drugstore accentuated meanings bestowed on Seirogan and created a tangible medical product that ordinary Japanese consumers could depend upon and associate themselves with. An icon of the health, vitality, and military prowess of Japan, Seirogan ultimately prescribed what it took to be a truly patriotic Japanese person - purchasing Seirogan.

\section{Conclusion}

Soon after General Douglas MacArthur was relieved of his duty as Supreme Commander of the Allied Powers in Japan in April 1951, Howard M. Handleman (1913-94), a well-respected veteran war correspondent and the Far East Director of the International News Service, sent Japanese publisher Dai Nippon Yübenkai Kōdansha a ten-page article reflecting on the legacy of MacArthur in postwar Japan. ${ }^{58}$ In this article, which was subsequently translated and published in the July issue of Japanese magazine King $u$ as 'General MacArthur and Seirogan', Handleman invites readers to the day when MacArthur first landed in Japan, a country 'still bristling with more than two million men under arms and still resentful for the blood it had lost to the conqueror whom MacArthur symbolized'. ${ }^{59}$ Almost everyone believed in August 1945 that it would be difficult, if not impossible, to occupy and democratise Japan. 'But it looks that way only to those who didn't know the story of the dysentery pills', retorts Handleman. 'MacArthur learned a lesson from those dysentery pills near the Yalu that he never forgot, and... the lesson he learned made him completely confident in 1945 that he could move into Japan without any trouble'. ${ }^{60}$

What was the story and what was the lesson? By now, the story should be a familiar one. During the Russo-Japanese war, Japanese soldiers were dying en masse from dysentery, but they were using every opportunity to avoid taking the foul-smelling dysentery pills - 'they crunched the pills into the ground with their boots, they dropped them in their pockets, they threw them into bushes' ${ }^{61}$ Given the seriousness of the situation, the highest field command held a staff conference to find a way to force soldiers to take the pills, and the solution was to issue the order in the name of the Emperor. MacArthur, who was in Manchuria as an aide-de-camp to his father, Lieutenant General Arthur MacArthur, Jr., did not anticipate that a mere wrapping of the order in the words of the Emperor would persuade Japanese soldiers. However, MacArthur was sorely mistaken. Once 'The order was issued; The soldiers took their pills; The army revived to whip the Russians; MacArthur was impressed'. ${ }^{6}$ According to Handleman, it was a momentous day for MacArthur and eventually for Japan as well - MacArthur 'was impressed so much that more than 40 years later, when his armies had defeated another Japanese army, he felt absolutely certain that the order of another Emperor to accept the conquerors without resistance would be obeyed to the letter'. ${ }^{63}$ And we all know what it meant to the postwar US occupation policy in Japan; the Emperor was exonerated of war responsibility, and the

\footnotetext{
${ }^{58}$ Howard M. Handleman, 'For Dai Nippon Yubenkai Kodansha', Howard M. Handleman Papers, Box 27, MacArthur: Anecdotes, 1947-80; Herbert Hoover Presidential Library.

${ }^{59}$ Ibid., 1.

${ }^{60}$ Handleman, op. cit. (note 58), 1.

${ }^{61}$ Handleman, op. cit. (note 58), 1.

${ }^{62}$ Handleman, op. cit. (note 58), 2.

${ }^{63}$ Handleman, op. cit. (note 58), 3.
} 
position of Japan was transformed from a quasi-totalitarian enemy state into an ally in the Pacific.

Did Seirogan spare the life of the Shōwa Emperor and change the course of history? Maybe in a convoluted way. Intriguing in its own right, the issue of Seirogan in its relation to MacArthur, let alone its impact on MacArthur's vision of postwar Japan, was not the main focus of this article. Rather, the unexpected story is introduced here as a snippet that shows in what ways this seemingly insignificant dysentery pill has been intimately connected to the lives of the Japanese people in the twentieth century.

As I argued in this article, Seirogan exemplifies a culmination of the convergence of a governmental initiative to enhance military capabilities, the commercial ingenuity of pharmaceutical manufacturers to profit from an expanding imperial culture, and a consumer response to patriotic exhortations. But the matrix that Seirogan allows us to glimpse is not a typical top-down governmental method of mobilising private sectors to manipulate public opinion for the cause of external imperialist expansion and domestic stability. In the eyes of the Japanese government, at least throughout the 1920s, jingoistic pharmaceutical manufacturers were more of a nuisance that could easily disrupt international relations than an effective tool of rallying ordinary Japanese people under the banner of the empire. Even with the government's indifference, if not hostility, pharmaceutical companies quickly recognised and exploited the pecuniary opportunities that Seirogan and its symbolism provided to them once the tide turned favourable from 1931. In turn, Japanese consumers reacted to these commercial sermons carefully anchored in patriotic and militaristic discourses and images by opening their wallets. In other words, Seirogan reveals an inverted power relation among the state, commercial sectors, and imperial citizens in the wartime Japanese empire, where pharmaceutical companies were at the driving seat.

As noted, the striking capability of pharmaceutical manufacturers to adapt to changing operational environments did not stop with the demise of the Japanese empire. The postwar metamorphosis of Seirogan from a symbol of empire into a contextless icon of health and travel in Japan further evinces the continued resilience and creativity of drug makers. This clever marketing tactic, which effectively bleached the stain of militarism off the label of Seirogan, also explains the seemingly ironic popularity of Seirogan as the symbol of the "quality of Japanese-made medicines' 64 among Korean and Chinese consumers who are often extremely bothered by Japan's historical amnesia.

On a general level, Seirogan thus shows the possibility that an entirely new perspective can be cast onto a familiar question using a commodity as a mediating material. As Andrew Gordon proved in his groundbreaking monograph that rewrote a history of modern Japan through a sewing machine, ${ }^{65}$ a commodity, especially a mass-produced consumer product, is a powerful medium that highlights an intricate web of connections between society and culture, between production and consumption, and between local and global. In this respect, a medicinal product is even more illuminating, for it also touches upon the dimensions of body, disease, and unavoidable control, and its efficacy does not discriminate between the bodies of the colonisers and the colonised. ${ }^{66}$ Seirogan is but one explicit example that glaringly illuminates this enmeshment.

\footnotetext{
64 Takehiko Koyanagi, 'More Asian Tourists Visiting Japan', The Japan Economic Journal, 12 November (1988), 5.

65 Andrew Gordon, Fabricating Consumers: The Sewing Machine in Modern Japan (Berkeley: University of California Press, 2011).

66 There is anecdotal evidence that Seirogan was also used by Korean guerrillas in Manchuria who were fighting against the Japanese Imperial Army in the 1940s. In this case, Seirogan also became a cure for anti-imperial campaign.
} 